\title{
Vitenskapelig uredelighet og Granskingsutvalget
}

I forskningsetikkloven foreskrives tre organer (1). De nasjonale forskningsetiske komiteer skal primært forebygge uredelig forskning ved å informere og gi råd. Det skal være regionale komiteer for medisinsk og helsefaglig forskningsetikk. Forskning som omfatter forsøk på mennesker, må godkjennes av regional komité. De nasjonale og regionale komiteene ble opprettet i hhv. 1990 og 1985. Lovfestingen ble begrunnet med at dette vil trygge komiteenes eksistens og uavhengighet (2, kap 7.1). Ved denne loven ble det også opprettet et nytt organ - Nasjonalt utvalg for gransking av redelighet i forskning, forkortet Granskingsutvalget.

Loven definerer uredelighet i forskning som «forfalskning, fabrikkering, plagiering og andre alvorlige brudd med god vitenskapelig praksis som er begått forsettlig eller grovt uaktsomt i planlegging, gjennomføring eller rapportering av forskning» $(1, \S 5)$. Kravet om «alvorlige» brudd betyr at det er avstand mellom det uredelige etter loven på den ene siden og de ideelle etiske krav på den annen side. Det er en sone mellom disse ytterpunktene der forskning kan være etisk kritikkverdig, men uten at den er et «alvorlig» brudd.

I lovens forarbeider legger Kunnskapsdepartementet til grunn at forskningsinstitusjonene har hovedansvaret for å behandle saker om mulig uredelighet (2, kap 7.2 og 11.1). Blir en institusjon kjent med et mulig tilfelle av uredelighet $\mathrm{i}$ forskning, er det i utgangspunktet institusjonen selv som skal håndtere saken. Det er da ofte hensiktsmessig å oversende saken til institusjonens forsknings-/redelighetsutvalg eller nedsette et særskilt undersøkelsesutvalg. I noen saker vil det også være aktuelt å engasjere eksterne sakkyndige. Kunnskapsdepartementet har forutsatt at universiteter og høyskoler skal orientere utvalget om saker som behandles lokalt (3). Institusjonene har også ansvar for oppfølgingen etter at undersøkelsen er avsluttet. Er konklusjonen at det foreligger uredelighet, kan det bli reist sak om arbeidsrettslige reaksjoner. Utgivere av de aktuelle publikasjoner bør varsles. Er forskningen finansiert av eksterne, bør bidragsyteren informeres (om sanksjoner mot uredelighet, se 2, kap 6.6).

Funksjonsfordelingen mellom forskningsinstitusjonene og Granskingsutvalget er slik at institusjonene kan anmode utvalget om å overta en sak. Dette kan f.eks. skje der en institusjon av habilitetsgrunner foretrekker at det nasjonale utvalget undersøker saken. Granskingsutvalget kan også gripe inn og overta en sak selv om institusjonen ønsker å behandle denne selv. Forskriften som Kunnskapsdepartementet har gitt med hjemmel i forskningsetikkloven sier at utvalget «kan $[\ldots]$ behandle saker av eget tiltak» $(4, \S 6)$. Forskriften sier ikke noe om når dette skal skje. Granskingsutvalgets skjønn blir derfor avgjørende. På bakgrunn av at institusjonene har primæransvaret for å undersøke saker om mulig uredelighet, vil utvalget bare i særlige tilfeller overta en sak. Dette kan bli aktuelt der habilitetsgrunner tilsier at det nasjonale utvalget bør behandle saken, hvis saken er særlig alvorlig, eller hvis institusjonens saksbehandling ikke anses betryggende.

Utvalget er en ressurs som institusjonene kan trekke på i saker som institusjonene selv behandler, bl.a. når det gjelder kravene som stilles for en rettssikker prosedyre. Oppbygging av en erfaringsbase vil bl.a. bidra til økt kunnskap om hvilke typer uredelighet som det særlig reises spørsmål om, og hvordan saker om mulig uredelighet bør behandles. Slik kunnskap er viktig i det forebyggende arbeidet og for å bidra til at det nasjonale utvalget kan bli den ressursen for institusjonene som forskningsetikkloven forutsetter. Både forskere og andre kan ta kontakt med Granskingsutvalget. Hvis slik kontakt skulle vise at et tilfelle av mulig uredelighet bør undersøkes, vil utvalget oversende saken til institusjonen, eller utvalget kan selv åpne gransking.

Når utvalget gransker en sak, fremgår reglene for behandlingen dels av forskningsetikkloven, dels av forskriften med hjemmel i denne og dels av en veileder som departementet har gitt til Granskingsutvalget (5). Når institusjonene undersøker en sak, er det ofte naturlig å anvende dette regelverket tilsvarende så langt det passer. Selv om utvalget har gransket en sak, er det uansett institusjonen som har det oppfølgende ansvaret med bl.a. mulige reaksjoner overfor forskeren. Offentleglova gjelder for institusjonenes dokumenter i saker om (mulig) uredelighet. Loven gir som hovedregel ikke adgang til å anonymisere navnet på forsker(e) som er i søkelyset. Når Granskingsutvalget undersøker en sak, gir forskningsetikkloven $\S 5$ adgang til å unnta dokumentene fra offentlighet frem til utvalget har gitt sin uttalelse. Etter dette er utvalgets dokumenter normalt offentlige.

Nasjonalt utvalg for vurdering av uredelighet i helsefaglig forskning, opprettet av Norges forskningsråd, behandlet 11 saker i 1994-2001 (2, kap 5.3.1). Det er trolig mørketall om vitenskapelig uredelighet både i Norge og andre land. Granskingsutvalget har siden det ble opprettet i 2007 foretatt én gransking (per november 2009). Dessuten er fire saker oversendt til institusjonene.

Det nasjonale utvalgets funksjon kan ikke bare ses i lys av antallet granskinger utvalget selv foretar. For det første vil enhver nå kunne henvende seg til et nasjonalt og uavhengig organ. Selv om utvalget oversender saken til institusjonen, skal utvalget orienteres om den lokale behandlingen. Institusjonene kan dermed i sin behandling av saker om mulig uredelighet bli kikket $\mathrm{i}$ kortene mer inngående enn tidligere. For det andre står nå et permanent organ til rådighet dersom det skulle oppstå en meget alvorlig sak der allmennhetens tillit til behandlingen tilsier at saken bør undersøkes av det nasjonale organet. For det tredje kan utvalget bidra til at forskningsinstitusjonenes behandling av saker om mulig uredelighet blir mer enhetlig enn tidligere. Utvalget ser det dessuten som en overordnet oppgave å søke samarbeid med forskingsinstitusjonene. Utvalgets funksjon som ressurs for institusjonene og dets kunnskapsbase om behandlingen av saker om uredelighet kan bidra til en slik dialog.

\section{Johan Giertsen}

giertsen@jur.uib.no

Johan Giertsen (f. 1957) er professor dr.juris ved Universitetet i Bergen og leder av Nasjonalt utvalg for gransking av redelighet i forskning.

\section{Oppgitte interessekonflikter: Ingen}

\section{Litteratur}

1. Lov av 30. juni $2006 \mathrm{nr}$. 56. Lov om behandling av etikk og redelighet i forskning (forskningsetikkloven).

Ot.prp. 58 (2005-2006). Om lov om behandling av etikk og redelighet i forskning.

3. Kunnskapsdepartementet. Informasjon om Nasjonalt utvalg for gransking av redelighet i forskning. Brev til universiteter og høyskoler 6.8. 2009. Referanse 200700316/HPG. Oslo: Kunnskapsdepartementet, 2009.

4. Forskrift om behandling av etikk og redelighet i forskning av 8. juni $2007 \mathrm{nr} .593$. . Veileder for Granskingsutvalgets arbeid. Oslo: Kunnskapsdepartementet, 2007. 